Gut, 1973, 14, 927-933

\title{
Liver biopsy and prognosis in acute liver failure
}

\author{
J. SCOTTO ${ }^{1}$, P. OPOLON, J. ÉtÉVÉ, D. VERGOZ, M. THOMAS, AND \\ J. CAROLI
}

From the Hospital of Saint-Antoine, Paris, INSERMUg, Paris, and CDTS, Paris

SUMMARY Liver biopsy was performed in 38 patients with fulminant hepatitis and coma and repeated in 22. Stereological estimation of hepatocyte volume was correlated with levels of clotting factors.

Early liver biopsy allowed prognosis in $55 \%$ of the cases. All patients with a hepatocyte volume of $<35 \%$ and thromboplastin time $\leq 10 \%$ died; all patients but two with hepatocyte volume $\geqslant 35 \%$ and thromboplastin time $>10 \%$ recovered consciousness $(n=9)$ or at least showed evidence of marked liver regeneration $(n=2)$.

On serial liver biopsy a significant increase in hepatocyte volume and clotting factors was only observed in patients who recovered consciousness. The estimated liver cell mass after regeneration in patients who recovered consciousness was $\geqslant 45 \%$ and $<45 \%$ in the patients who did not.

The very sophisticated treatments recently introduced for the treatment of acute hepatic failure point to the need for quantitative parameters of liver function and liver regeneration in order to decide which is the most adequate treatment and the best moment to start it.

The aim of this study is to estimate the severity of liver damage by early liver biopsy in patients with acute liver failure; the ability of the liver to regenerate demonstrated by serial liver biopsies; and a correlation of this parameter with liver function reflected in coagulation studies.

\section{Patients}

During the past seven years, 106 patients were admitted in coma and acute liver failure due to viral hepatitis (104 cases), mushroom poisoning (one case), and INH overdose (one case). In 10 patients coma did not exceed grade III and all survived. Of 96 patients in coma grade IV, 24 $(25 \%)$ recovered consciousness and $18(18.7 \%)$ survived.

Early liver biopsy (one day before to five days after the onset of coma) was performed in 38 patients (fig 1), using a Menghini $1.4 \mathrm{~mm}$ needle. Clotting fractions (PPSB or antihaemophilic concentrated plasma) were administered at the time of the first liver biopsy if the thromboplastin time was under

'Author's address: Hopital St Antoine, 184 Rue du Fbg St Antoine 75571 Paris, Cedex 12, France.

Received for publication 8 May 1973.

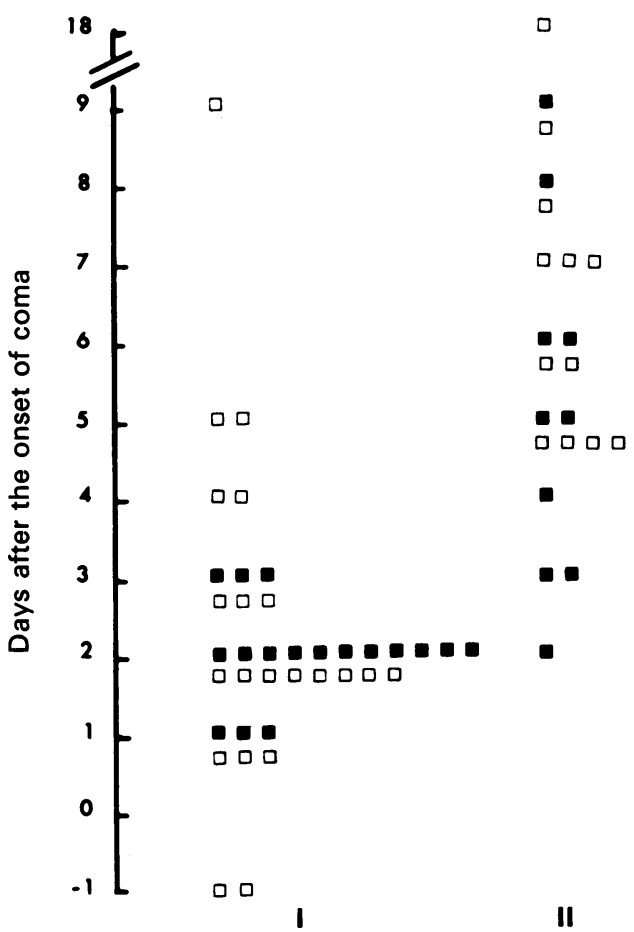

Fig 1 Time of first (I) and second (II) liver biopsy.

Fulminant liver cell failure (beginning of coma 0 to three days after the onset of icterus).

$I=$ first liver biopsy or patients with only one early

liver biopsy $(n=17), I I=$ second liver biopsy $(n=10)$

$\square$ Acute liver cell failure (beginning of coma four to

30 days after the onset of icterus $). I(n=21) I I(n=12)$ 


\begin{tabular}{lllllc}
\hline & $\begin{array}{l}\text { Recovery of } \\
\text { Consciousness and } \\
\text { Secondary Death }\end{array}$ & $\begin{array}{l}\text { Recovery of } \\
\text { Consciousness with } \\
\text { Survival }\end{array}$ & $\begin{array}{l}\text { Decerebration } \\
\text { and Death with } \\
\text { Liver Regeneration }\end{array}$ & $\begin{array}{l}\text { Irreversible Coma } \\
\text { and Death without } \\
\text { Liver Regeneration }\end{array}$ & Total \\
\hline $\begin{array}{l}\text { Patients with } \\
\text { maximal coma } \\
\text { grade IV }\end{array}$ & 1 & 11 & & & 34 \\
$\begin{array}{l}\text { Patients with } \\
\text { maximal coma }\end{array}$ & 0 & 5 & 17 & 4 \\
$\begin{array}{l}\text { S grade III } \\
\text { Total }\end{array}$ & 1 & 4 & 0 & 0 & 38 \\
\hline
\end{tabular}

Table I Details of cases in 38 patients with acute liver cell failure and early liver biopsy

$10 \%$ or if spontaneous bleeding was observed. Peritoneal bleeding was never observed even when clotting fractions had not been given. Of these 38 patients (table I), 16 recovered consciousness (15 survived and one died suddenly of a massive left haemothorax); five died after decerebration while the liver was regenerating; 17 died without any improvement in consciousness or in liver function.

Liver biopsy had been repeated (without the administration of clotting fractions) two to 18 days later in 22 patients (in 10 who survived, in one who recovered consciousness but died later, in four with early decerebration and liver degeneration, and in seven with irreversible coma without any liver regeneration).

\section{Methods}

Thromboplastin time was measured before liver biopsy and before the administration of clotting fractions using Quick's method. The differential dosage of factor $\mathrm{V}$ was determined by a modification of Owren's technique. Results were expressed as percentages of the normal level, which is usually 60 to $100 \%$ for thromboplastin time, factors II, $\mathrm{V}$, and VII + X. At the same time a platelet count was performed. For statistical analysis values under $10 \%$ are expressed as $5 \%$.

Biopsies were fixed in Carnoy's medium, embedded in paraffin, cut at $5 \mu$, and stained by Masson trichrome. A stereological count of hepatocytes was obtained as previously described (Scotto, Theodoropoulos, and Lageron, 1970; Caroli, Opolon, Scotto, Hadchouel, Thomas, and Lageron, 1971) by applying to the liver needle biopsies a stereological counting method defined for histological sections by Chalkley in 1943 (Chalkley, 1943; Chalkley, Cornfield, and Park, 1949), An optical projection of a histological section is laid under the network of a set number of points (30 to 40 points) when points coinciding with hepatocytes are counted (fig 2). The ratio between the counted points and the total number of points is in theory equal to the ratio between hepatocyte volume and whole liver volume.

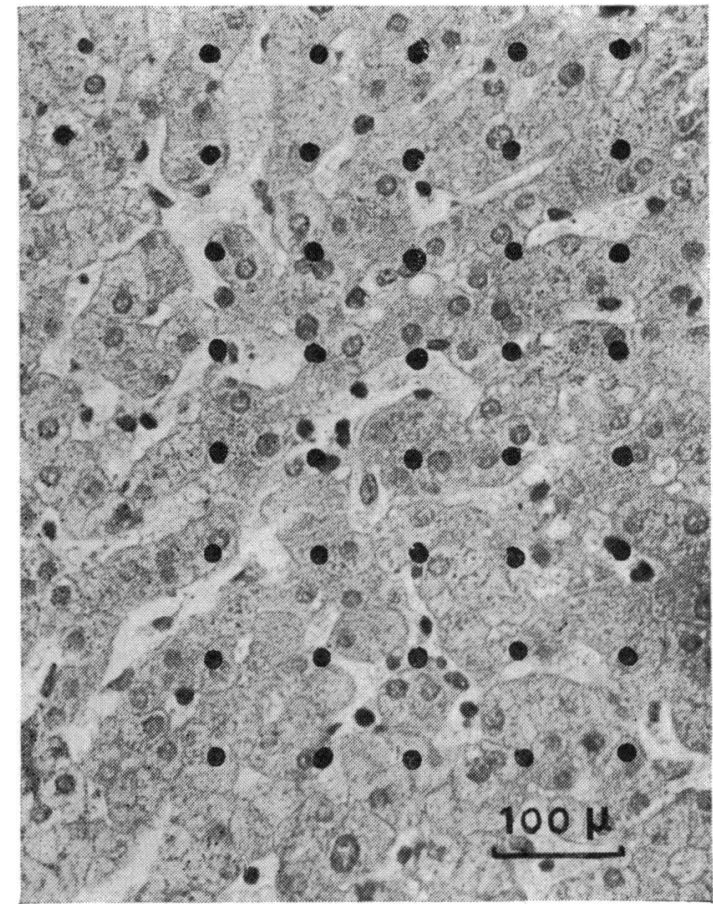

Fig 2 Normal liver. On this microscopical area 34 points out of 40 coincide with hepatocytes. As many fields as possible, not less than 40, randomly chosen, are counted. The ratio between counted points and total number of points is in theory equal to the ratio between hepatocyte volume and whole liver volume. In normal liver hepatocyte volume $=85 \pm 5 \%$.

Hepatic volume is established by calculating the mean value for results obtained by counting 30 to 40 separate areas (total number of points $=1600$ ). On a normal liver needle biopsy the hepatocyte volume thus measured is $85 \pm 5 \%$ (fig 2 ).

\section{Results}

Results are summarized in table II. A significant increase (fig 3 ) is observed for hepatocyte volume, 


\begin{tabular}{|c|c|c|c|c|c|c|c|c|c|}
\hline \multirow[t]{2}{*}{ Group } & \multicolumn{3}{|c|}{$\begin{array}{l}\text { Hepatocyte Volume }(\%) \\
\text { (mean value } \pm S D)\end{array}$} & \multicolumn{3}{|c|}{$\begin{array}{l}\text { Thromboplastin Time }(\%) \\
\text { (mean value } \pm S D)\end{array}$} & \multicolumn{3}{|c|}{$\begin{array}{l}\text { Factor } V(\%) \\
\text { (mean value } \pm S D)\end{array}$} \\
\hline & \multicolumn{2}{|l|}{$\begin{array}{l}\text { First or Only } \\
\text { One Biopsy }\end{array}$} & Second Biopsy & \multicolumn{2}{|l|}{$\begin{array}{l}\text { First or Only } \\
\text { One Biopsy }\end{array}$} & Second Biopsy & $\begin{array}{l}\text { First or Only } \\
\text { One Biopsy }\end{array}$ & \multicolumn{2}{|c|}{ Second Biopsy } \\
\hline $\begin{array}{l}\text { Recovery of } \\
\text { consciousness } \\
\text { (group I) }\end{array}$ & $\begin{array}{l}40 \pm 19 \\
(n=16)\end{array}$ & $P<0.01$ & $\begin{array}{l}56 \pm 12 \\
(n=11)\end{array}$ & $\begin{array}{l}20 \pm 17 \\
(n=16)\end{array}$ & $P<0.001$ & $\begin{array}{l}50 \pm 27 \\
(n=11)\end{array}$ & $\begin{array}{l}35 \pm 23 \\
(n=16)\end{array}$ & $P<0.001$ & $\begin{array}{l}73 \pm 23 \\
(n=11)\end{array}$ \\
\hline $\begin{array}{l}\text { Decerebration } \\
+ \text { liver } \\
\text { regeneration } \\
\text { (group II) }\end{array}$ & $\begin{array}{l}32 \pm 16 \\
(n=5)\end{array}$ & $P<0.30$ & $\begin{array}{l}42 \pm 5 \\
(n=4)\end{array}$ & $\begin{array}{l}21 \pm 25 \\
(n=5)\end{array}$ & $P<0.30$ & $\begin{array}{l}29 \pm 15 \\
(n=4)\end{array}$ & $\begin{array}{l}26 \pm 18 \\
(n=5)\end{array}$ & $P<0.30$ & $\begin{array}{l}44 \pm 28 \\
(n=4)\end{array}$ \\
\hline $\begin{array}{l}\text { Death without } \\
\text { any improvement } \\
\text { (group III) }\end{array}$ & $\begin{array}{l}19 \pm 10 \\
(n=17)\end{array}$ & $P<0.50$ & $\begin{array}{l}16 \pm 10 \cdot 5 \\
(n=7)\end{array}$ & $\begin{array}{l}10 \cdot 2 \pm 6 \cdot 6 \\
(n=17)\end{array}$ & $P<0.90$ & $\begin{array}{l}10 \cdot 8 \pm 5 \cdot 5 \\
(n=5)\end{array}$ & $\begin{array}{l}14 \pm 9 \cdot 8 \\
(n=17)\end{array}$ & $P<0.98$ & $\begin{array}{l}12 \cdot 6 \pm 8 \\
(n=5)\end{array}$ \\
\hline
\end{tabular}

Table II Comparative results in 38 cases for hepatocyte volume, thromboplastin time, and factor $V$ between first and second liver biopsy in groups I, II, and III

thromboplastin time, and factor $\mathrm{V}$ in patients who recovered consciousness (group I). A moderate and insignificant increase in these parameters is present in decerebrated patients with regeneration of the liver (group II). No significant change characterizes (fig 4) those dead without any improvment (group III).

A comparative study of hepatocyte volume,

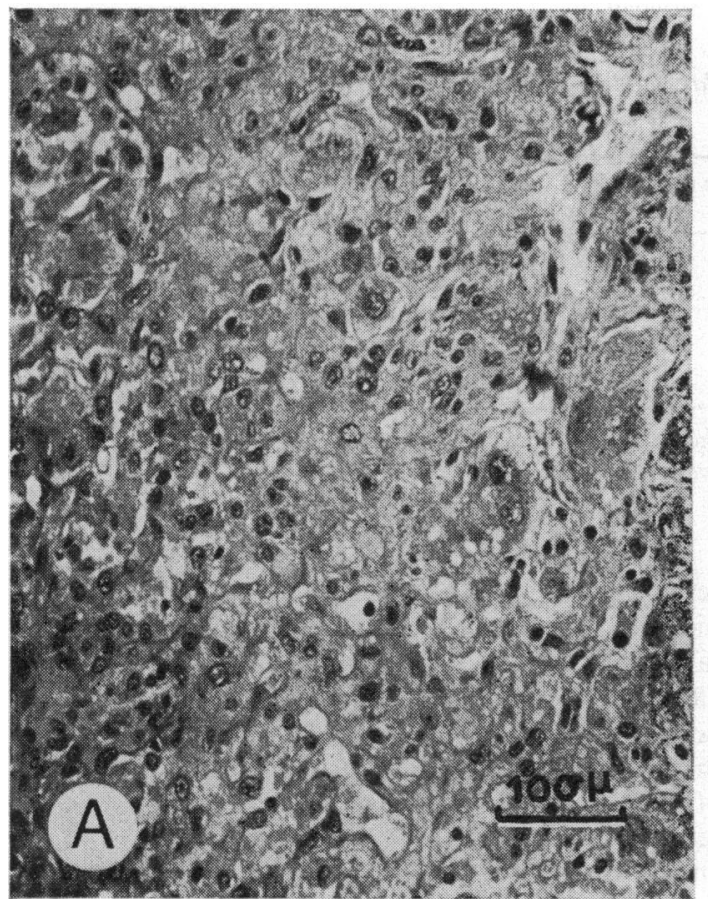

thromboplastin time, and factor V between groups I II, and III at the moment of the first liver biopsy (table III) shows a significant difference for these three parameters between groups I and III, for hepatocyte volume and thromboplastin time between groups II and III, and no discriminating parameter between groups I and II.

At the time of the second liver biopsy (table III)

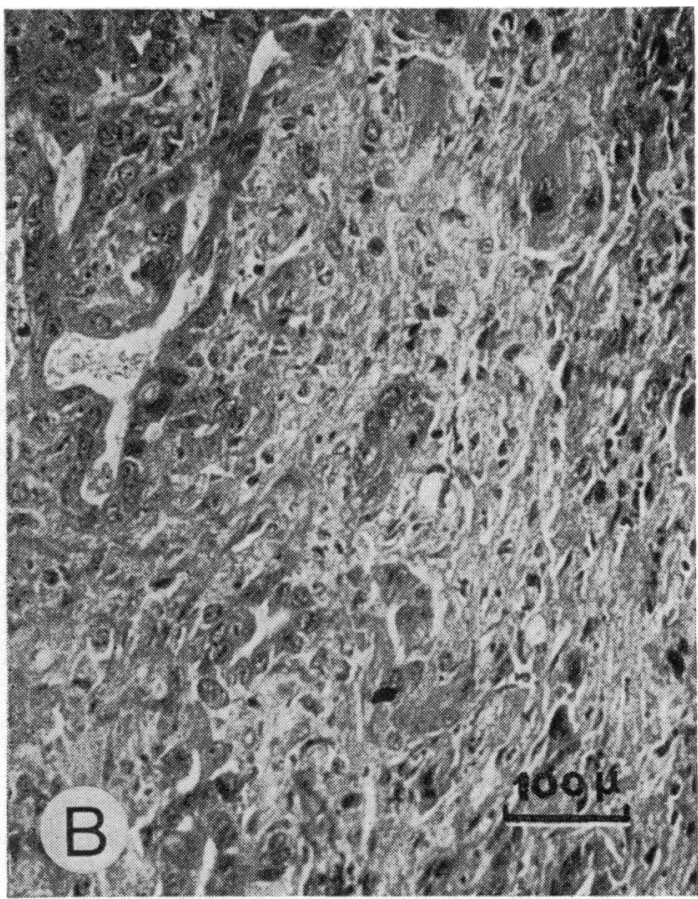

Fig 3 Fulminant viral hepatitis. Death without any liver regeneration.

$\mathbf{A}=$ Liver biopsy one day before the onset of coma. Hepatocyte volume $=17 \%$
$\mathrm{B}=$ Liver biopsy seven days later on the sixth day of coma. Hepatocyte volume $=14 \%$ 

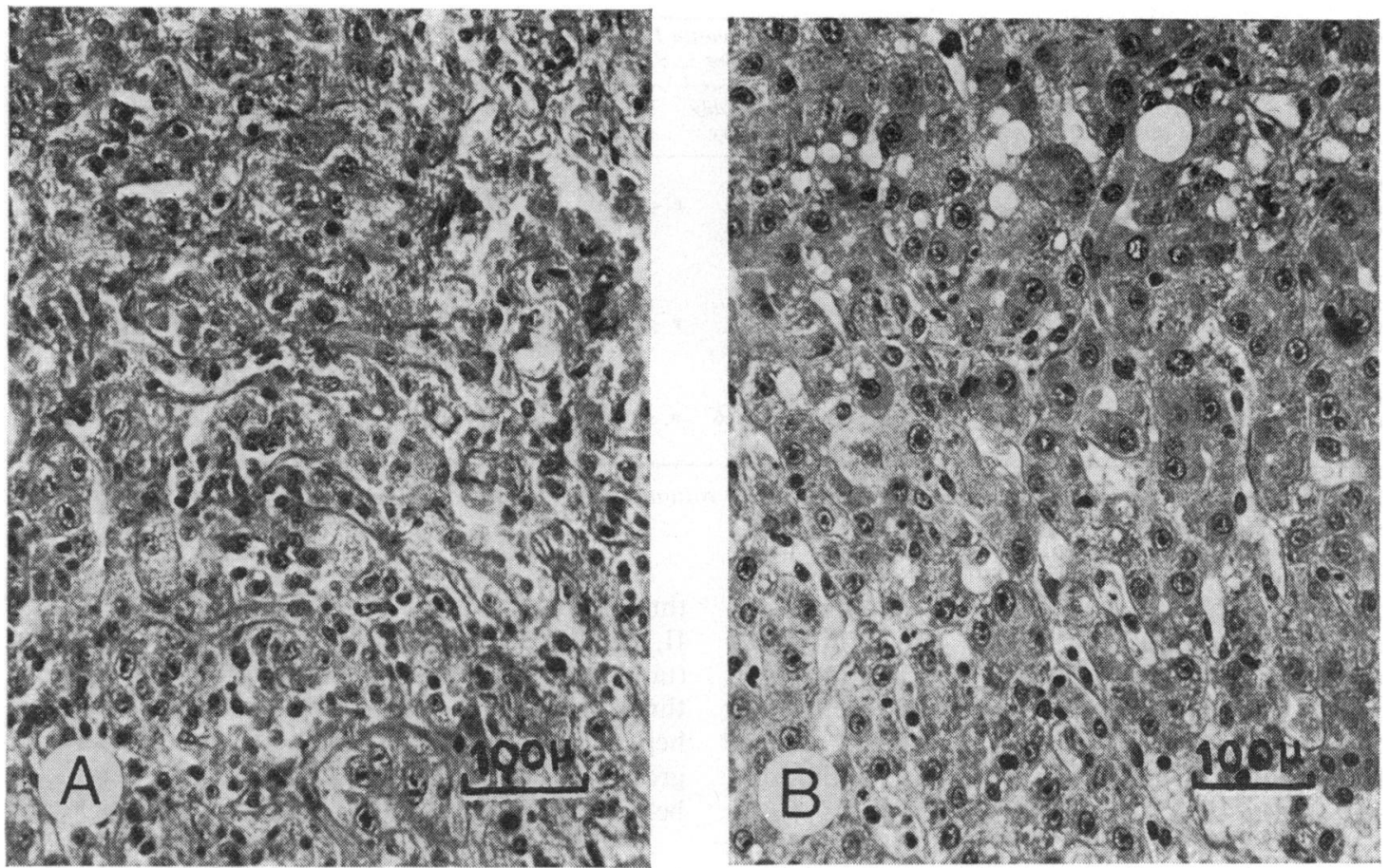

Fig 4 Fulminant viral hepatitis. Recovery of consciousness and survival.
$\mathrm{A}=$ liver biopsy on the second day of coma.
B = liver biopsy on the fifth day of coma (three Hepatocyte volume $=27 \%$ days later). Hepatocyte volume $=69 \%$

\begin{tabular}{|c|c|c|c|c|c|c|}
\hline \multirow{2}{*}{$\begin{array}{l}t \text { Test between } \\
\text { Groups }\end{array}$} & \multicolumn{2}{|c|}{ Hepatocyte Volume } & \multicolumn{2}{|c|}{ Thromboplastin time } & \multicolumn{2}{|l|}{ Factor $V$} \\
\hline & $\begin{array}{l}\text { First or Only } \\
\text { One Biopsy }\end{array}$ & Second Biopsy & $\begin{array}{l}\text { First or Only } \\
\text { One Biopsy }\end{array}$ & Second Biopsy & $\begin{array}{l}\text { First or Only } \\
\text { One Biopsy }\end{array}$ & Second Biopsy \\
\hline $\begin{array}{l}\text { I-III } \\
\text { I-II } \\
\text { II-III }\end{array}$ & $\begin{array}{l}<0.001 \\
<0.50 \\
<0.05\end{array}$ & $\begin{array}{l}<0.001 \\
<0.05 \\
<0.001\end{array}$ & $\begin{array}{l}<0.001 \\
<0.80 \\
<0.05\end{array}$ & $\begin{array}{l}<0.01 \\
<0.20 \\
<0.40\end{array}$ & $\begin{array}{l}<0.05 \\
<0.50 \\
<0.10\end{array}$ & $\begin{array}{l}<0.001 \\
<0.10 \\
<0.05\end{array}$ \\
\hline
\end{tabular}

Table III Results in 38 cases of $t$ test (Student-Fischer) for hepatocyte volume, thromboplastin time, and factor $V$ between groups I, II, and III at the time of first and second liver biopsies

only hepatocyte volume is a consistently discriminating measurement between the three groups. Thromboplastin time only differentiates between groups I and III, factor V between groups I and III and groups II and III.

Discrepancies between hepatocyte volume and clotting factors are not related to the administration of clotting fractions. At the time of the first liver biopsy, blood samples were withdrawn before the administration of clotting factors. At the second liver biopsy 20 patients out of 22 did not receive any blood fractions. The two other cases receiving exchange transfusion were excluded from the statistical analysis.
For greater precision a similar statistical analysis restricted to the 22 cases with two serial liver biopsies was carried out. Results (summarized in table IV) are very close to those obtained for the 38 overall cases. A comparative study (table V) between the three groups for hepatocyte volume, thromboplastin time, and factor $\mathrm{V}$ at the moment of the first liver biopsy is similar. At the time of the second liver biopsy (table V) both hepatocyte volume and factor $\mathrm{V}$ distinguish the three groups. Therefore these two parameters may be considered as satisfactory tests for liver regeneration.

In the patients who recovered consciousness $45 \%$ or higher estimated liver cell mass (fig 5) at the second 


\begin{tabular}{|c|c|c|c|c|c|c|c|c|c|}
\hline \multirow[t]{2}{*}{ Group } & \multicolumn{3}{|c|}{$\begin{array}{l}\text { Hepatocyte Volume }(\%) \\
\text { (mean value } \pm S D)\end{array}$} & \multicolumn{3}{|c|}{$\begin{array}{l}\text { Thromboplastin Time }(\%) \\
\text { (mean value } \pm S D)\end{array}$} & \multicolumn{3}{|c|}{$\begin{array}{l}\text { Factor } V \\
\text { (mean value } \pm S D)\end{array}$} \\
\hline & First Biopsy & \multicolumn{2}{|c|}{ Second Biopsy } & First Biopsy & \multicolumn{2}{|c|}{ Second Biopsy } & First Biopsy & \multicolumn{2}{|c|}{ Second Biopsy } \\
\hline $\begin{array}{l}\text { Recovery of } \\
\text { consciousness } \\
\text { (group I) }\end{array}$ & $\begin{array}{l}37 \pm 14 \\
(n=11)\end{array}$ & $P<0.01$ & $\begin{array}{l}56 \pm 12 \\
(n=11)\end{array}$ & $\begin{array}{l}20 \pm 8 \\
(n=11)\end{array}$ & $P<0.01$ & $\begin{array}{l}50 \pm 27 \\
(n=11)\end{array}$ & $\begin{array}{l}39 \pm 22 \\
(n=11)\end{array}$ & $P<0.01$ & $\begin{array}{l}73 \pm 23 \\
(n=11)\end{array}$ \\
\hline $\begin{array}{l}\text { Death without } \\
\text { any improvement } \\
\text { (group III) }\end{array}$ & $\begin{array}{l}14 \pm 8 \\
(n=7)\end{array}$ & $P<0.7$ & $\begin{array}{l}16 \pm 10 \\
(n=5)\end{array}$ & $\begin{array}{l}7 \pm 4 \\
(n=7)\end{array}$ & $P<0.3$ & $\begin{array}{l}11 \pm 5 \\
(n=5)\end{array}$ & $\begin{array}{l}13 \pm 11 \\
(n=7)\end{array}$ & $P<0.9$ & $\begin{array}{l}12 \pm 8 \\
(n=5)\end{array}$ \\
\hline
\end{tabular}

Table IV Results in groups I, II, and III for the 22 patients with two serial biopsies

\begin{tabular}{|c|c|c|c|c|c|c|}
\hline \multirow{2}{*}{$\begin{array}{l}\text { t Test between } \\
\text { Groups }\end{array}$} & \multicolumn{2}{|c|}{ Hepatocyte Volume } & \multicolumn{2}{|c|}{ Thromboplastin Time } & \multicolumn{2}{|l|}{ Factor $V$} \\
\hline & First Biopsy & Second Biopsy & First Biopsy & Second Biopsy & First Biopsy & Second Biopsy \\
\hline $\begin{array}{l}\text { I-III } \\
\text { I-II } \\
\text { II-III }\end{array}$ & $\begin{array}{l}<0.01 \\
<0.5 \\
<0.1\end{array}$ & $\begin{array}{l}<0.001 \\
<0.05 \\
<0.01\end{array}$ & $\begin{array}{l}<0.001 \\
<0.9 \\
<0.001\end{array}$ & $\begin{array}{l}<0.01 \\
<0.2 \\
<0.05\end{array}$ & $\begin{array}{l}<0.01 \\
<0.4 \\
<0.2\end{array}$ & $\begin{array}{l}<0.001 \\
<0.01 \\
<0.05\end{array}$ \\
\hline
\end{tabular}

Table V Results in 22 patients with serial liver biopsy of t test (Student-Fischer) for hepatocyte volume, thromboplastin time, and factor $V$ between groups $I, I I$, and III at the time of first and second liver biopsies

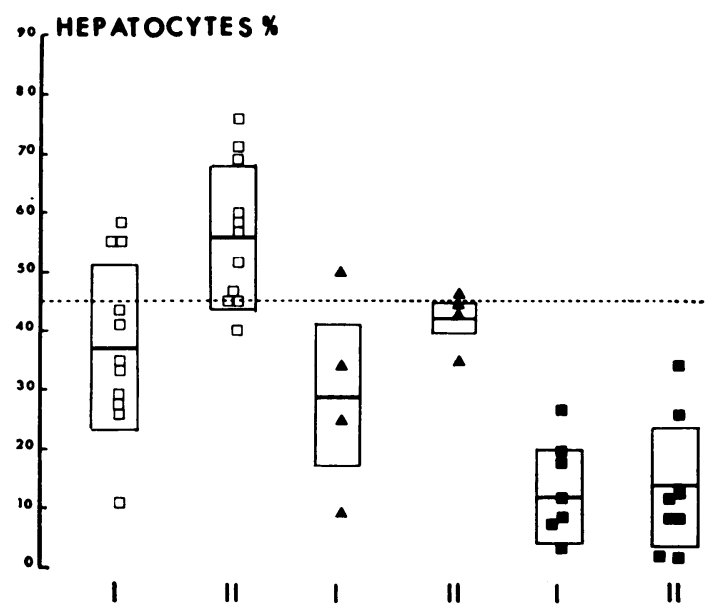

Fig 5 Comparison of hepatocyte volume at first and second liver biopsies in 22 cases with serial liver biopsy.

death without any improvement (group I)

$\Delta$ decerebration + liver regeneration (group II)

$\square$ recovery of consciousness (group III)

On the second liver biopsy all patients with hepatocyte volume $\geqslant 45 \%$ recovered consciousness, all those with $\leqslant 45 \%$ did not (with the exception of two cases). liver biopsy was observed in all cases except one but in all the patients who died (with or without some liver regeneration) except one it was under $45 \%$.

A good correlation was established between hepatocyte volume and thromboplastin time (fig 6) and between hepatocyte volume and factor V (fig 7).

No relationship could be established between the depth or duration of coma and hepatocyte volume or clotting factors.

On the first liver biopsy in 38 patients (fig 8) all patients $(n=10)$ with hepatocyte volume $<35 \%$ and thromboplastin time $\leqslant 10 \%$ died; all but two patients with hepatocyte volume $\geqslant 35 \%$ and thromboplastin time $>10 \%$ recovered consciousness $(n=9)$ or decerebrated with liver regeneration $(n=2)$; no prognosis can be established for patients with hepatocyte volume $<35 \%$ and thromboplastin time $>10 \%$ (recovery of consciousness $=7$, decerebration and liver regeneration $=3$, death $=5$ ).

Similar results for prognosis in the same 38 patients were obtained when using hepatocyte volume and factor $V$ (fig 9 ).

\section{Comments}

Early liver biopsy during acute liver failure allows a good estimation of remaining functional hepato- 


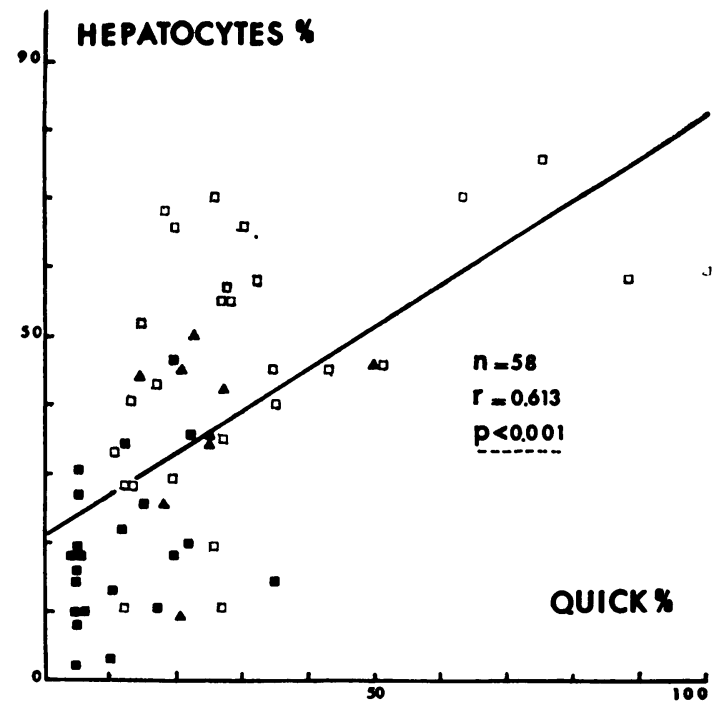

Fig 6 Overall correlation between hepatocyte volume and thromboplastin time.

death without any improvement

$\Delta$ decerebration + liver regeneration

recovery of consciousness

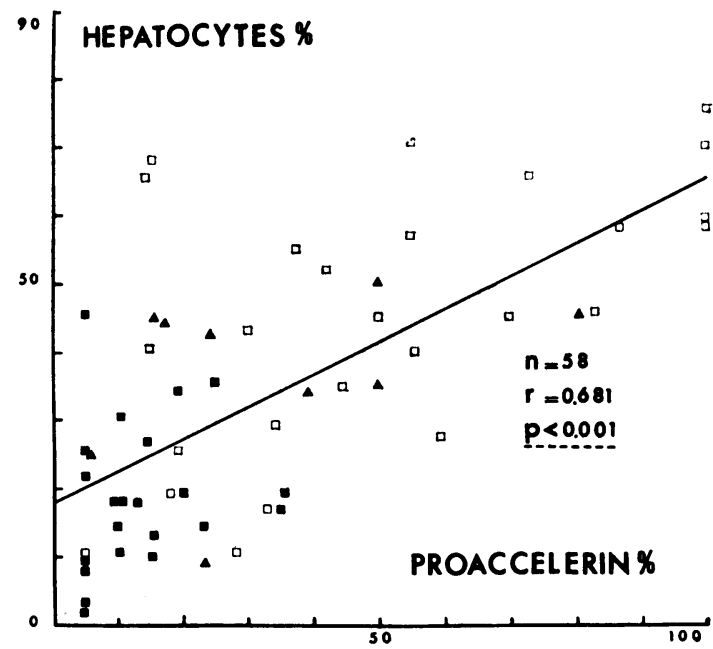

Fig 7 Overall correlation between hepatocyte volume and factor $V$.

death without any improvement

$\Delta$ decerebration + liver regeneration

$\square$ recovery of consciousness

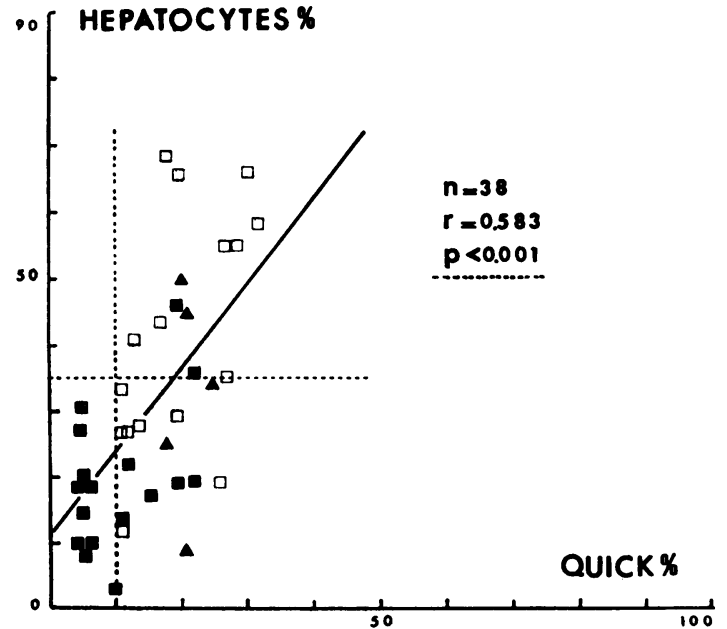

Fig 8 Correlation between hepatocyte volume and thromboplastin time on early liver biopsy and prognostic value.

death without any improvement $\Delta$ decerebration + liver regeneration recovery of consciousness

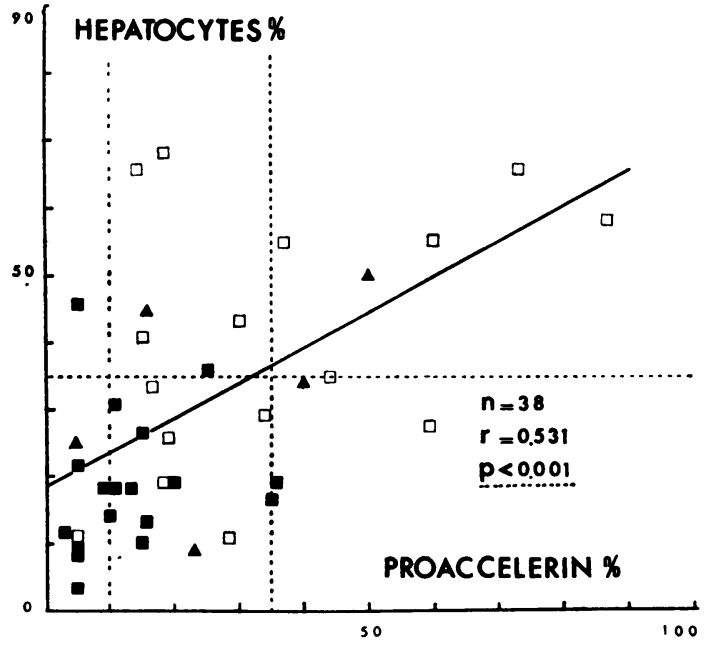

Fig 9 Correlation between hepatocyte volume and factor $V$ on early liver biopsy and prognostic value

death without any improvement

$\Delta$ decerebration \pm liver regeneration

$\square$ recovery of consciousness 
cyte volume and prognosis in approximately half of the cases $(21 / 38=55 \%)$.

These results confirm preliminary studies already published (Scotto et al, 1970; Caroli et al, 1971). Stereological estimation of liver cell volume gives better results for prognosis than most of the parameters reviewed in previous studies (Trey, 1967; Colombi et al, 1967; Opolon et al, 1970; Caroli et al, 1971): liver size estimated by percussion, blood ammonia level, clotting factors. Good correlation with liver function as reflected by clotting factors can be established. Thus a liver cell mass estimation may be very helpful when clotting factors are modified by such circumstances as exchange transfusions, interhuman cross-circulation, evidence of intravascular coagulation, and heparin therapy. The key value of a $40 \%$ intact liver cell mass as a significant parameter for prognosis was recently confirmed by Paliard, Patricot, and Grimand (1972) in 44 cases of liver cell failure.

However, prognosis could not be established on early liver biopsy in 17 cases out of $38(44 \%)$. In two cases (fig 4) hepatocyte volume was repectively $36 \%$ and $46 \%$, thromboplastin time $22 \%$ and $19 \%$. Biopsy was performed on the fourth day of coma in the first case and insufficient liver regeneration may be suspected. In the second case very early biopsy on the first day of coma may have not reflected further extension of necrosis the following days. In the other 15 cases hepatocyte volume ranged from $10 \%$ to $34 \%$ and thromboplastin time from $11 \%$ to $26 \%$. There is no correlation between hepatocyte volume and thromboplastin time in these 15 cases $(n=15, r=0.086, P<0 \cdot 10)$. The discrepancy between these two parameters should be related to heterogeneity of necrotic lesion within the liver. However, preliminary studies by counting for the same patient liver biopsies just before death and liver samples taken during early nec- ropsy did not show any marked difference. One may suppose that most of these patients were in a very critical situation and prognosis was unpredictable on the first liver biopsy only.

As no bleeding occurred in any of these 38 patients, and only in one case out of 44 in Paliard's series (Paliard et al, 1972), it seems reasonable now to introduce serial liver biopsy as a method for evaluating liver regeneration and prognosis in acute liver failure. When clotting factors are not a reliable guide, it should be interesting to correlate liver cell mass with another biological parameter such as the galactose elimination test (Tygstrup, 1966). Moreover systematically repeated liver biopsy may help to determine the critical cell mass allowing recovery of consciousness and survival after regeneration of the liver. From this preliminary study such a mass would be $45 \%$ of the total liver volume.

\section{References}

Caroli, J., Opolon, P., Scotto, J., Hadchouel, P., Thomas, M., and Lageron, A. (1971). Elements du pronostic au cours des comas par atrophie hépatique aiguë. Presse méd., 79, 463-466.

Chalkley, H. W. (1943). Method for the quantitative morphologic analysis of tissues. J. nat. Cancer Inst., 4, 47.

Chalkley, H. W., Cornfield, J., and Park, H. (1949). A method for estimating volume surface ratios. Science, 110, 295.

Colombi, A., Thölen, H., Engelhart, G., Duckert, F., Hecht, Y., and Koller, F. (1967). Blutgerinnungs-faktoren als Index für den Schweregrad einer akuter Hepatitis. Schweiz. med. Wscht, 97, 1716-1721

Paliard, P., Patricot, F., and Grimand, J. A. (1972). Les altérations histologiques des hepatites graves et leur évolution. A propos de $\mathbf{4 5}$ observations suivies par biopsies. Ann. Gastroent. Hépat., 8, 133-150.

Opolon, P., Hadchouel, P., Del Corso, A., and Caroli, J. (1970), Ammoniémie et équilibre acido-basique au cours de l'atrophie aiguě du foie. Ann. Méd. interne, 121, 1-15.

Scotto, J., Theodoropoulos, G., and Lageron, A. (1970). Hepatite aigue: applicátion d'une méthode stéréologique en microscopie optique. Spéculations pronostiques. Rev. med.-chir. Mal. Foie, 45, 61-64.

Trey, C. (1967). Fulminant hepatic surveillance study. (First progress report).

Tygstrup, N. (1966). Determination of the hepatic elimination capacity (Lm) of galactose by single injection. Scand. J. clin. Lab Invest., 18, Suppl. 92, 118-125. 